\title{
Late liver metastasis of medullary thyroid cancer with low calcitonin levels - successfully cured by radiofrequency
}

\author{
Późny przerzut do wątroby raka rdzeniastego tarczycy z niskim stężeniem \\ kalcytoniny skutecznie wyleczony metodą radioablacji
}

\author{
Abdallah Al-Salameh ${ }^{1}$, Camille Baudry ${ }^{1}$, Jean François Gautier ${ }^{2}$, \\ Marie-Elisabeth Toubert ${ }^{3}$, Hélène Bihan ${ }^{1,4}$, Régis Cohen ${ }^{5}$ \\ ${ }^{1}$ Department of Endocrinology, Diabetes Mellitus, and Metabolic Disease, Avicenne University Hospital, Assistance Publique \\ - Hôpitaux de Paris, Paris XIII University, Bobigny, France \\ ${ }^{2}$ Department of Diabetes Mellitus and Endocrinology, Lariboisière University Hospital, Assistance Publique — Hôpitaux de Paris, \\ Paris 7 University Paris-Diderot, Paris, France \\ ${ }^{3}$ Department of Nuclear Medicine, Saint-Louis University Hospital, Assistance Publique — Hôpitaux de Paris, Paris 7 University \\ Paris-Diderot, Paris, France. \\ ${ }^{4}$ UMR U557 INSERM U1125 INRA Centre de Recherche en Nutrition Humaine-IdF, F-93017 Bobigny, France \\ ${ }^{5}$ Department of Endocrinology and Diabetes Mellitus, Delafontaine Hospital, Saint-Denis, France
}

\begin{abstract}
A 28-year-old female consulted in 1994 for a left thyroid nodule known for two years with documented progression. Left lobe resection was performed initially followed by total thyroidectomy without lymph node dissection in September 1994. Pathological examination concluded on unilateral $10 \times 40 \mathrm{~mm}$ medullary thyroid carcinoma (MTC). RET mutation was negative. Basal and pentagastrin-stimulated CT levels had been normal from 1994 to 2008 when her CT level was found to be elevated at $33 \mathrm{ng} / \mathrm{L}$ and increased subsequently to $111 \mathrm{ng} / \mathrm{L}$ in 2010. In accordance with guidelines, cervical ultrasound was performed repeatedly with negative results. After discussion in a multidisciplinary meeting and with patient's consent, an F-Dopa PET scan was proposed in disagreement with guidelines. This scan showed unique uptake in liver segment VI, which was confirmed by MRI. CT levels reached to $253 \mathrm{ng} / \mathrm{L}$ when she finally accepted treatment. In February 2013 we performed radiofrequency ablation of the lesion, which allowed normalisation of CT levels. This observation highlights the possibility of late recurrence of MTC. We could propose that for MTC patients with low-calcitonin levels-recurrences F-DOPA-PET/CT is a good diagnostic tool to use in case of repeatedly negative US neck studies. (Endokrynol Pol 2016; 67 (3): 326-329)
\end{abstract}

Key words: medullary thyroid carcinoma; calcitonin; radiofrequency

\section{Streszczenie}

Chora w wieku 28 lat zgłosiła się do lekarza w 1994 roku z powodu lewostronnego guzka tarczycy wykrytego 2 lata wcześniej, z potwierdzoną progresją. Wykonano resekcję lewego płata tarczycy. Totalną tyreoidektomię wykonano we wrześniu 1994 roku bez usunięcia węzłów chłonnych. W badaniu patomorfologicznych stwierdzono jednostronnego raka rdzeniastego tarczycy (MTC) o wymiarach $10 \times 40 \mathrm{~mm}$. Wynik badania w kierunku mutacji RET był ujemny. Stężenia kalcytoniny (CT, calcitonin), podstawowe i po stymulacji pentagastryną, były prawidłowe od 1994 roku. Do 2008 roku, kiedy stwierdzono podwyższone stężenie CT wynoszące 33 ng/l, a następnie jego dalszy wzrost do $111 \mathrm{ng} / \mathrm{l}$ w 2010 roku. Zgodnie z zaleceniami powtórnie wykonano badanie USG szyi, w którym nie stwierdzono nieprawidłowości. Po omówieniu przypadku na spotkaniu wielodyscyplinarnego zespołu i uzyskaniu zgody chorej przeprowadzono badanie F-Dopa PET (niezgodnie z zaleceniami), w którym wykazano pojedyncze ognisko wychwytu w segmencie VI wątroby, co zostało potwierdzone w badaniu MRI. Kiedy chora w końcu zaakceptowała leczenie, stężenia CT zwiększyły się do 253 ng/l. W lutym 2013 roku wykonano ablację zmiany prądem o częstotliwości radiowej, co pozwoliło uzyskać normalizację stężeń CT w 2015 r. Ta obserwacja zwraca uwagę na możliwość późnej wznowy. Autorzy sugerują, że u chorych z MTC z ponownie stwierdzonym niskim stężeniem kalcytoniny wybór F-DOPA-PET/CT jako metody diagnostycznej jest dobrym rozwiązaniem w przypadku powtórnych ujemnych wyników USG szyi. (Endokrynol Pol 2016; 67 (3): 326-329)

Słowa kluczowe: rak rdzeniasty tarczycy; kalcytonina; prąd o częstotliwości radiowej

\section{Introduction}

Medullary thyroid carcinoma (MTC) is a rare endocrine tumour that represents $5-10 \%$ of all thyroid cancers. MTC can be sporadic $(75 \%)$, or inherited $(25 \%)$ either as isolated disease or associated with other endocrine diseases such as pheochromocytoma or hyperparathyroidism [1]. The pathogenesis of MTC is tightly related to activating mutations of the RET (rearranged during transfection) proto-oncogene, which are germline in 


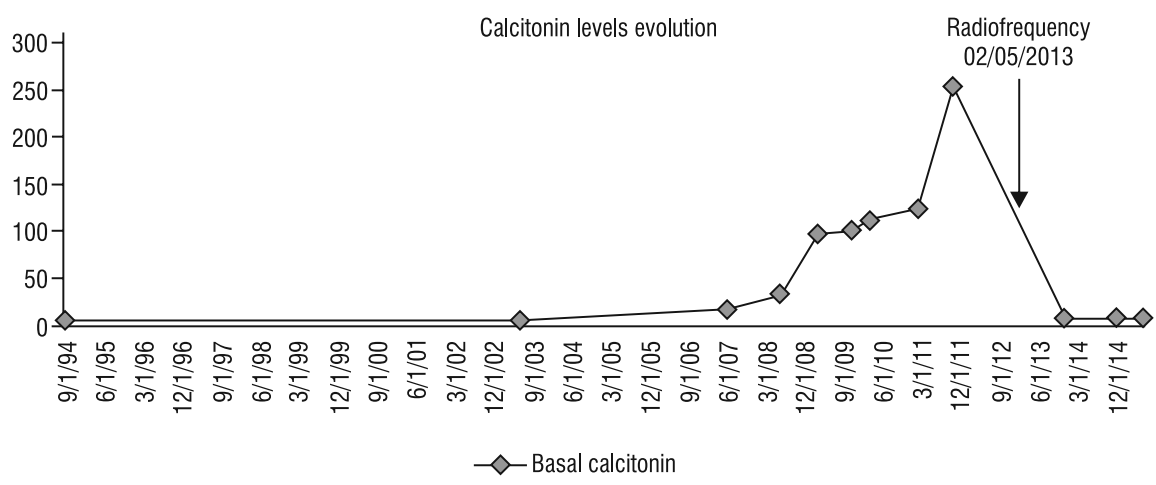

Figure 1. Calcitonin levels evolution from 1994 to 2015

Rycina 1. Zmiany stężenia kalcytoniny w okresie od 1994 do 2015 roku

most hereditary cases (in approximately $98 \%$ of cases) and somatic in many sporadic ones (in approximately $45 \%$ of cases) [2]. Calcitonin (CT) is its specific marker with a high specificity and sensitivity; its level is related to tumour volume and prognosis [3].

Although the mortality due to MTC represents $13.4 \%$ of the mortality of all thyroid cancers [4], it has a relatively good prognosis with 10 -year survival rates for patients with stages I, II, III, and IV of $100 \%, 93 \%$, $71 \%$, and $21 \%$, respectively [5]. MTC spreads rapidly to regional (cervical) lymph nodes. In the end stage of MTC, the usual sites of systemic metastasis are liver, lungs, and bones [6]. Thus, most MTC patients who have extensive regional lymph node metastases or systemic disease are not cured by total thyroidectomy with bilateral neck lymph nodes dissection $[5,7]$. In cases of persistent MTC or late recurrence radiotherapy and/or chemotherapy have low success rates and did not show evidence of lengthening the survival [1]. Debulking surgery, loco regional approaches such as radiofrequency, have rare indications and consequently rare successes.

Due to its high diagnostic accuracy, CT levels are used to follow MTC patients after initial treatment in order to detect persistent and recurrent disease. Moreover, CT levels are very useful in guiding workup. Recent American guidelines have been published indicating that in the case of post operative CT elevation less than $150 \mathrm{ng} / \mathrm{L}$ it is recommended to look for recurrence in the neck or to keep a watchful attitude. We present a young patient with late MTC liver metastasis with a mild CT elevation of $111 \mathrm{ng} / \mathrm{L}$ but without cervical lymph node metastases, who was cured after unique radiofrequency treatment.

\section{Case presentation}

A 28-year-old female, with no prior history, consulted in 1994 for a left thyroid nodule known for two years with documented progression. Left lobe resection was performed in September 1994. A suspected follicular carcinoma at frozen section motivated totalisation without lymph node dissection. Pathological examination was compatible with a unilateral $37 \times 27 \times 18 \mathrm{~mm}$ MTC (T2NxMx) with neither vascular invasion nor extra capsular extension. Immunostaining was positive for CT and CEA and negative for thyroglobulin. There was no C cell hyperplasia. A search for RET germline mutation in the patient's peripheral blood lymphocytes was negative.

Post-operative calcitonin levels were undetectable, while CEA levels were at $1.6 \mu \mathrm{g} / \mathrm{L}$. Of note, no CT levels were available before surgery. Basal (not stimulated) CT levels (normal level < $10 \mathrm{ng} / \mathrm{L}$ ) had been normal from September 1994 to June 2007 when her basal CT level was found to be elevated at $17 \mathrm{ng} / \mathrm{L}$, and it increased subsequently to $111 \mathrm{ng} / \mathrm{L}$ in March 2010 (Fig. 1). Interestingly, pentagastrin-stimulated CT levels were elevated in 2003 (46 ng/L; normal < $10 \mathrm{ng} / \mathrm{L})$ but with normal basal CT levels. In accordance with guidelines [1] cervical ultrasound was performed repeatedly between 2007 and 2010 with negative results. After discussion in a multi-disciplinary meeting and with the patient's consent, F-DOPA PET/CT scan was proposed as a diagnostic tool even though this was in disagreement with guidelines, especially recommendations 47 and 48 in the recent guidelines [1]. F-DOPA-PET/CT scan showed unique uptake in liver segment VI with no cervical uptake (Fig. 2A). Hepatic ultrasound echography did not localise the lesion, but magnetic resonance imaging confirmed the results of F-DOPA-PET/CT by showing a 7-mm lesion with moderate hyperintensity on T2-weighted images, low signal intensity on T1-weighted images, and high signal intensity in diffusion sequences (Fig. 2B). No histologic analysis was done. Since the patient did not agree to receive local treatment, watchful waiting was done until CT levels increased to $253 \mathrm{ng} / \mathrm{L}$ (October 2011) — albeit a normal CEA level of $1.10 \mu \mathrm{g} / \mathrm{L}$ - when she finally 

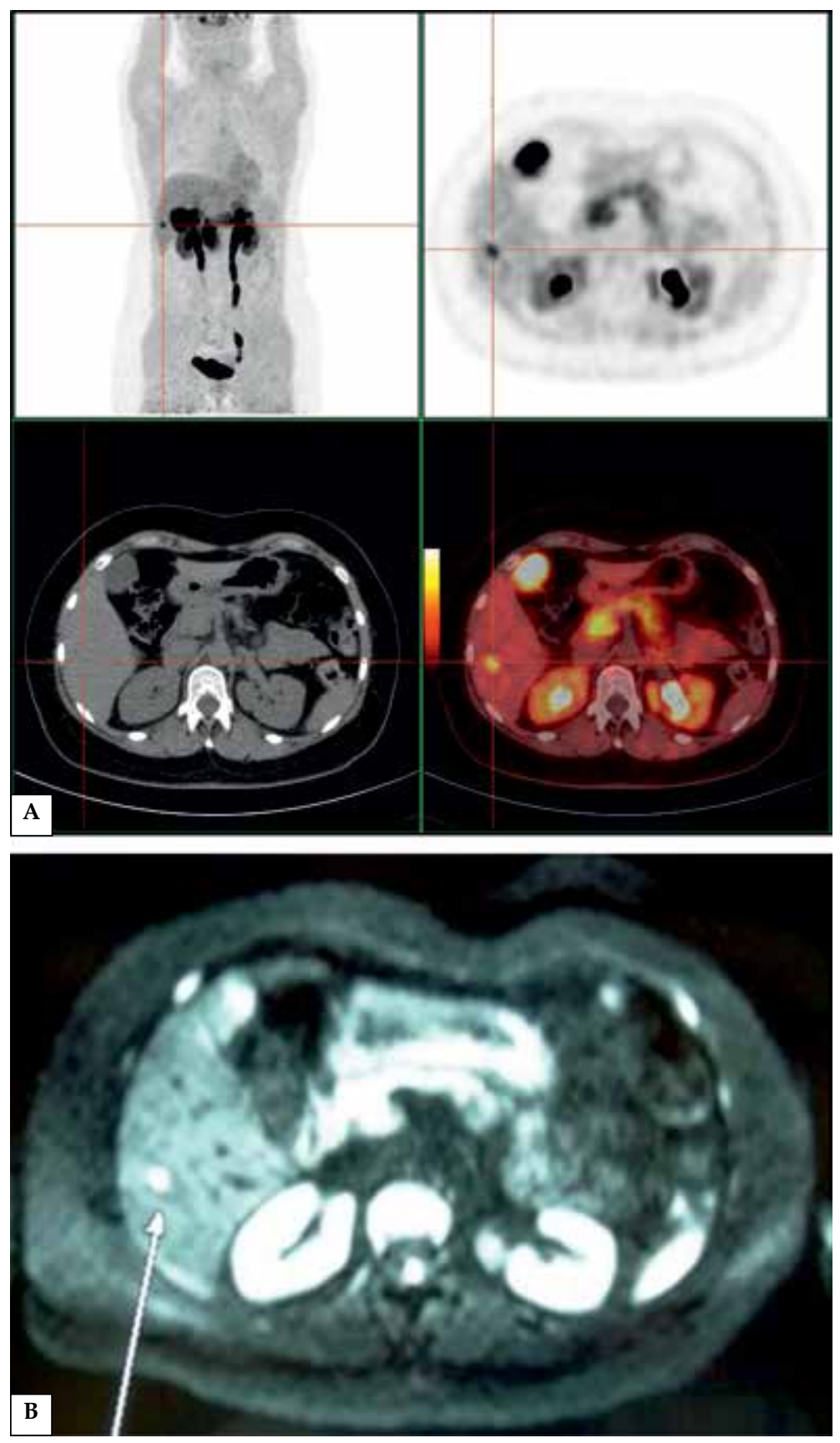

Figure 2A. F-DOPA PET/CT imaging showing high uptake lesion in the liver; B. Abdominal MRI showing a hyper signal intensity lesion in the liver (diffusion-weighted imaging)

Rycina 2A. Badanie F-DOPA PET/CT pokazujące zmianę w wątrobie charakteryzująca się silnym wychwytem znacznika; B. Badanie MRI jamy brzusznej pokazujące zmianę o zwiększonej intensywności w wątrobie (obrazowanie dyfuzyjne)

accepted treatment. In February 2013, when she was 47 years old, we performed radiofrequency ablation of the lesion, which allowed normalisation of CT levels for a 26 month-period (up to her last follow-up visit in 2015).

\section{Discussion}

This is certainly the first case of late unique liver metastases detected by F-DOPA-PET/CT scan and suc- cessfully treated by radiofrequency with such a long follow-up. This observation shows the limits of the recommended management of MTC patients in some cases. We could propose that for MTC patients with low-calcitonin levels-recurrences, F-DOPA-PET/CT is a good diagnostic tool to be used in the case of repeatedly negative US neck studies.

Regional lymph node invasion is frequent and occurs early in MTC patients, as reported in 
a 101 patients-series by Scollo et al. [8]. In sporadic MTC, lymph node metastases were observed in the central compartment and in the ipsilateral and contralateral jugulo-carotid chain in 50,57 , and $28 \%$ of cases, respectively. In hereditary MTC, lymph node metastases were identified in the central compartment, and in the ipsilateral and contralateral jugulo-carotid chain in 45, $36,19 \%$ of cases, respectively. Liver metastases are less frequent and occur in $45 \%$ of patients with advanced MTC, and sometimes they are life-threatening. They are often multiple and disseminated throughout the hepatic parenchyma; and usually they are not accessible to surgery, percutaneous ethanol, radiofrequency ablation, or chemoembolisation, nor do they respond well to systemic therapy [8]. Imaging techniques to detect persistent or recurrent MTC include cervical and abdominal US, neck and chest CT, three-phase contrastenhanced CT, contrast-enhanced MRI, bone scintigraphy, and FDG-PET/CT [9]. In advanced MTC diseases, the sensitivity of these tests in localising metastatic disease ranges between $50 \%$ and $80 \%$. In a recent study on 41 patients, liver metastases were demonstrated in less than $50 \%$ by MRI (49\%), CT (41\%), US (41\%), and FDG-PET/CT (27\%) [9]. F-DOPA-PET/CT could have superior sensitivity and specificity [10].

This case report has several implications, albeit with some caveats.

In recent guidelines grade $\mathrm{C}$ recommendations 47 and 48 indicate that patients with CT levels $<150 \mathrm{ng} / \mathrm{L}$ should have only physical examination and US of the neck and should be followed with physical examinations, measurement of serum levels of CT and CEA, and US every six months, and only in the case of CT level $>150 \mathrm{ng} / \mathrm{L}$ should other imaging procedures be considered [1]. This is what had been done in our patient. However, repeated US studies of the neck showed no evidence of local disease, while the hepatic lesion was more than suspicious. The presence of unique liver metastasis with no regional lymph node and only a CT level of $111 \mathrm{ng} / \mathrm{L}$ is an exception. Imperial et al. reported a previous case but with higher CT levels [11].

Secondly, 18F-FDOPA PET/CT could help clinicians to find recurrence in patients with repeatedly negative cervical US studies [10]. The lesion-based detection rate by F-DOPA-PET/CT is around $70 \%$ and probably it could be of value in cases of mild elevation of CT levels where other imaging techniques have a low sensitivity.

Thirdly, we cured our patient by radiofrequency with a long follow-up. That might be related to lesion dimensions because radiofrequency ablation is associated with better results in smaller lesions. Usually radiofrequency is used for cytoreduction in cases of disseminated diseases. Recurrences or deaths have been reported after use of this therapy [12].

Finally, this observation highlights the possibility of late recurrence of MTC (3.3\% among a series of 453 patients) [13]. Thus, MTC-cured patients need long-term follow-up and annual CT level determination.

In conclusion, future studies with sufficient numbers of patients are mandatory in order to determine whether patients who have MTC recurrence with CT $<150 \mathrm{ng} / \mathrm{L}$ gain some benefit by searching for liver metastases. The precise way in which F-DOPA-PET/CT can be used for the assessment of patients with MTC recurrence remains uncertain, but some data suggest that F-DOPA-PET/CT may be useful for risk stratification and could indicate some local therapies.

\section{References}

1. Wells SA Jr, Asa SL, Dralle H et al. Revised American Thyroid Association Guidelines for the Management of Medullary Thyroid Carcinoma The American Thyroid Association Guidelines Task Force on Medullary Thyroid Carcinoma. Thyroid 2015; 25: 567-610. doi: 10.1089/thy.2014.0335.

2. Elisei R, Cosci B, Romei C et al. Prognostic significance of somatic RET oncogene mutations in sporadic medullary thyroid cancer: a 10-year follow-up study. J Clin Endocrinol Metab 2008; 93: 682-687.

3. Cohen R, Campos JM, Salaün C et al. Preoperative calcitonin levels are predictive of tumor size and postoperative calcitonin normalization in medullary thyroid carcinoma. Groupe d'Etudes des Tumeurs a Calcitonine (GETC). J Clin Endocrinol Metab 2000; 85: 919-22.

4. Kebebew E, Ituarte PH, Siperstein AE et al. Medullary thyroid carcinoma: clinical characteristics, treatment, prognostic factors, and a comparison of staging systems. Cancer 2000; 88: 1139-1148.

5. Modigliani E, Cohen R, Campos JM et al. Prognostic factors for survival and for biochemical cure in medullary thyroid carcinoma: results in 899 patients. The GETC Study Group. Groupe d'etude des tumeurs à calcitonine. Clin Endocrinol (Oxf) 1998; 48: 265-273.

6. Cohen R, Buchsenschutz B, Estrade P et al. Causes of death in patients with medullary cancer of the thyroid. GETC. Groupe d'Etude des Tumeurs à Calcitonine. Presse Med 1996; 25: 1819-1822.

7. Fromigue J, De Baere T, Baudin E et al. Chemoembolization for liver metastases from medullary thyroid carcinoma. J Clin Endocrinol Metab 2006; 91: 2496-2499.

8. Scollo C, Baudin E, Travagli JP et al. Rationale for central and bilatera lymph node dissection in sporadic and hereditary medullary thyroid cancer. J Clin Endocrinol Metab 2003; 88: 2070-2075.

9. Giraudet AL, Vanel D, Leboulleux $S$ et al. Imaging medullary thyroid carcinoma with persistent elevated calcitonin levels. J Clin Endocrinol Metab 2007; 92: 4185-4190.

10. Soussan M, Nataf V, Kerrou K et al. Added value of early 18F-FDOPA PET/CT acquisition time in medullary thyroid cancer. Nucl Med Commun 2012; 33: 775-779.

11. Imperiale A, Greget $M, C$ habrier $G$ et al. Solitary hepatic metastasis from medullary thyroid carcinoma mimicking atypical hemangioma: insights from multimodality diagnostic approach by MRI, F-18 FDG and F-18 FDOPA PET/CT. Clin Nucl Med 2010; 35: 434-437.

12. Wertenbroek MW, Links TP, Prins TR et al. Radiofrequency ablation of hepatic metastases from thyroid carcinoma. Thyroid 2008; 18: 1105-1110.

13. Franc S, Niccoli-Sire P, Cohen R et al. Complete surgical lymph node resection does not prevent authentic recurrences of medullary thyroid carcinoma. Clin Endocrinol (Oxf) 2001; 55: 403-409. 
